\author{
Kyyakbayeva $U^{1}$ Iniyatova $A .^{2}$ Turdaly $T .^{3}$ \\ ${ }^{12}$ Abay Kazakh national pedagogical university, \\ Kazakhstan, Almaty \\ ${ }^{3}$ Kazakh Ablai Khan University of International Relations and World Languages, \\ Kazakhstan, Almaty
}

\title{
FEATURES OF SOCIAL-PEDAGOGICAL WORK WITH CHILDREN FROM LOW-INCOME FAMILIES
}

\section{Abstract}

This article is not only about the peculiarities of the work of a social teacher with a low-income family, but also about improving the social status of children in the family, about organizing social assistance, about helping them in solving the problem independently, and deeper understanding of own spiritual world and organizing different events to join the ranks of society. Socio-economic problems in the country can not be solved because of different age characteristics, and factors that affect their lives, particularly, the impact factors on the child due to the improper relationship between children and parents in the family; insufficient well-being of children in society or school; isolation from the social environment due to the various depressions; the influence of a low social situation, etc. This affects the child's psychology and after these circumstances, the child's potential for inspiration will be reduced, such as education, training, the desire to live, empathy with the leader of society, and consequently,this article emphasizes the special moments of social and pedagogical work, based on the works of comprehensive foreign scientists.

Keywords: «family», «support», «teenager», «low-income family», «financial situation», «social teacher», «social and pedagogical support», «high school students», «adaptation», «support», «assistance»;

\author{
Ұ.Қ. Қыякбаева ${ }^{1}$ А.Е. Иниятова ${ }^{2}$ Т.Л. Тұрдаль ${ }^{3}$ \\ ${ }^{12}$ Абай атындагы Қазақ ұлттық педагогикальққ университеті, \\ Алматы қ., Қазақсстан \\ ${ }^{3}$ Абылай хан атындавы Қазақ халықаралық құатынастар және әлем тілдері университеті, \\ Алматы қ̧., Қазақ̧стан
}

\section{АЗ ҚАМТЫЛҒАН ОТБАСЫНДАҒЫ БАЛАЛАРМЕН ӘЛЕУМЕТТІК-ПЕДАГОГИКАЛЫК ЖҰМЫСТЫН ЕРЕКШЕЛІКТЕРІ}

\section{Анцдатпа}

Бұл мақалада әлеуметтік педагогтың аз қамтылған отбасымен жұмыс жасау ерекшеліктерін көрсетіп қана қоймай отбасыдағы балалардың әлеуметтік жағдайын көтеру, әлеуметтік көмекті ұйымдастыру, тек көмек күтуші ғана емес проблеманы шешу үшін өздігінен жол табуына көмектесу, рухани жан дүниесін танып білуі, қоғам көшіне ілесіп, қатарға қосу жұмыстарын ұйымдастыру туралы айтылған. Еліміздегі түрлі жас ерекшеліктеріне қарай әлеуметтік мәселенің шешімін таба алмай жатқан тұсы балалар мәселесі екендігін жеткізіп, олардың өміріне әсер етуші факторлар, атап айтқанда: отбасындағы ата-ана арасындағы қарым-қатынастың дұрыс болмауынан балаға әсер ету факторы; балалардың қоғамда немесе мектепте өзін кем сезінуі; түрлі депрессияға ұшырап, өзін өмір сүру ортасынан бөлектеу; әлеуметтік жағдайдың төмендігінің әсері; т.б. бала психологиясына әсер ететіндігі және осы жағдайлардан кейін бала үшін білім алу, оқу, өмір сүруге талпыну, қоғам көшімен бірге ілесу сынды шабыттың потенциалы бәсеңдейтіндігін жеткізіп, жан-жақты шетел ғалымдарының еңбектеріне сүйене отырып әлеуметтік-педагогикалық жұмыс жүргізудің ерекше тұстарын айтады.

Түйін сөздер: «отбасы», «бала», «жасөспірімдік шақ», «жоғары сынып оқушылары», «материалдық жағдай», «әлеуметтік педагог», «аз қамтылған отбасы», «әлеуметтік-педагогикалық қолдау», «бейімделу», «қолдау», «көмек көрсету»; 
ВЕСТНИК КазНПУ им. Абая, серия «Педагогические науки», №1(65), 2020 г.

Кыякбаева У.К. ${ }^{1}$ Иниятова А.Е. ${ }^{2}$ Турдаль Т.Л. ${ }^{3}$

${ }^{12}$ Казахского Национального педагогического университета имени Абая,

2. Алматы, Казахстан

${ }^{3}$ Казахский университет Международных отношений и мировых языков

имени Абылай хана, г. Алматы, Казахстан

\title{
ОСОБЕННОСТИ СОЦИАЛЬНО-ПЕДАГОГИЧЕСКОЙ РАБОТЫ С ДЕТЬМИ ИЗ МАЛООБЕСПЕЧЕННЫХ СЕМЕЙ
}

\begin{abstract}
Аннотация
В данной статье рассматриваются особенности работы социального педагога с малообеспеченной семьей, но и повышение социального положения в семье, организация социальной помощи, организация работы включения в ряды общества о познании духовного мира и поиске путей самостоятельного решения проблем. Социально- экономические проблемы в стране не могут быть решены по различным факторам, влияющие на жизнь, в частности: фактор воздействия родителей на ребенка из за не благоприятного климата в семье, недостаточное самочувствие детей в обществе подверженных различным депрессиям, влияние низкой социальной ситуации в стране и др. Эти факторы влияют на психологию ребенка, что в дальнейшем влечёт за собой снижение уровня обучаемости и работоспособности детей. Таким образом в данной статье подчёркиваются важность проведения социально- педагогических работ, всесторонне опираясь на труды зарубежных учёных.

Ключевые слова: «семья», «дети», «подростковый возраст», «старшеклассники», «материальное положение», «социальный педагог», «малообеспеченная семья», «социальнопедагогическая поддержка», «адаптация», «поддержка», «оказание помощи»;
\end{abstract}

Any society has a social problem. This is a problem with lives, lifestyle and various age characteristics. Due to various age characteristics, teenager problems are not solved in the country too. Because there are several factors that affect their lives. Particularly, the impact factor on the child due to the wrong relationship between parents in the family; the lack of feeling of the teenager in society or school; depression and isolation from the environment; the influence of low social status; it is obvious that these factors affect the psychology of the child. After such situations, the child's potential for inspiration slows down, such as getting an education, learning, striving to live, and accompanying the leader of society. A teenager can search for the desired item from the other side. No one is responsible for defining if whether this direction right or wrong.

Since 1991, the "Social pedagogy" branch has been officially introduced in the country on the basis of the document, and a social teacher has been working. A General social teacher is a specialist who organizes educational work with children in various socio-cultural settings and helps them adapt to society.[1]

The work of a social educator with children and adolescents began in different countries at different times and for different purposes. At the same time, a social teacher is expected to work with a family and a teenager who has certain social problems. In this regard, one of the goals of a social teacher is to provide social and pedagogical support to teenagers from low-income families in secondary schools. Not only to support but also improve the social situation of students, organize social assistance, help in self-finding solutions to problems, not only receiving assistance, but also to organize work on studying the spiritual world, included in the system.

Therefore, after determining the goal of supporting low-income families and adolescents, the social educator works on setting several tasks for himself. Towards them:

1. drawing up a list of low-income families, orphans, children left without parental care and large families in secondary schools, registration of documents;

2. identification of socio-pedagogical factors affecting teenagers from low-income families;

3. identification and systematization of features of providing social support to children from low-income families in secondary schools.

First of all, let's get acquainted with the concepts of family, low-income family, teenager and providing them with social pedagogical support.

The family is a complex social system that has the character of social institutions and small social groups. 
According to 5-2 paragraph of $1^{\text {st }}$ article of the Law of the Republic of Kazakhstan of July 17, 2001 No. 246" on state targeted social assistance", low-income persons (families) are persons (families) who have an average per capita income below the poverty line established in regions, cities of national significance, and the capital, and these persons have the right to receive targeted social assistance. [2]

A teenager is the end of childhood, the transition from childhood to adulthood. Usually cover from 1011 to $14-15$ years.

Adolescence is the age when systems of knowledge of the world, moral trust, principles and dreams, and the concept of evaluation are actively formed. It is at this age that social educators should strictly take into account that children's moral consciousness is growing. The formation of the personality of teenagers depends on the nature of the moral case and moral experience. For teenagers, an important milestone of growth, the formation of their self-awareness, understanding of their needs as a person.

The results of the study show that adolescents have an interest in their inner life, their personal quality, and compensation for material and spiritual needs. He opens up his self, seeks to know the strengths and weaknesses in his own self. This contributes to the entire mental life of the teenager, the nature of his cognitive activity, the formation of his view with others, communication with people.

The family is distinguished by economic space, an interdependent way of life, emotional and moral ties, mutual assistance, assistance, and protection. Thus, the family is one of the institutions of socialization of the young generation, performing the function of ensuring the safety of any person. Currently, many families need help and support to fully perform the functions required by society. Such assistance is provided by incomplete and large families, single families raising children with disabilities, foster children with disabled parents, refugees, migrants, the unemployed, etc. families are in need. Therefore, it is very important to provide and support socio-pedagogical and pedagogical assistance to low-income families.

Socio-philosophical aspects of socio-pedagogical support for students were considered in ancient philosophy (Democritus, Plato, etc.), Renaissance philosophy (T.Campanella, M. Montane, etc.), and in philosophical and pedagogical anthropology (Bud, V. I. Maksakova, A. N. Orlov, K. D. Ushinsky, V. N. Filippov, V. D. Shadrikov, etc.).

The psychological foundations of child support are revealed by B. G. Ananiev, A. G. Asmolov, L. S. Vygotsky, A. Maslow, S. Rogers, V. I. Slobodchikov, B. Shapiro, and others.

The analysis of psychological and pedagogical literature in pedagogical science and practice revealed a different classification of stages of supporting activity of the teacher. T.V. Anokhina demonstrates the stages of pedagogical support for teenagers in the activity of a social teacher: 1) diagnostics; 2) search; 3) contractual; 4) activity; 5) reflexive. V. V. Kulishov developed stages of pedagogical support for students ' self-realization: 1) identification of difficulties; 2) search for the causes of difficulties with students; 3) discussion of results; 4) manifestation of joint activities. Stages of pedagogical support for teenagers S.V.Boykova: 1) goal; 2) activity; 3) reflex-predictive.

In the direction of pedagogical support (V. A. Gorshkova, R. V. Ovcharova, V.V. Morozova, etc.), Starting from the humanistic pedagogy of the XVIII century, up to the present time it is connected with the experience of development and application (I. Pestalozzi, K. D. Ushinsky, V. P. Kashchenko, V. N. Soroka, A. S. Makarenko, I.Korchak, S. A. Kalabalin, etc.). To solve life problems that arise in the conditions of life and physical, spiritual, and intellectual capabilities of children, the idea of social pedagogical support is relevant, since each child sets new professional tasks for the teacher. Therefore, for a social teacher working with children from low-income families, it is important to be fluent in methods of pedagogical support for the personal development of children and adolescents. Social pedagogical support for the majority of researchers (V. A. Belichev, M. V. Zhdanov, N. S. Morozov, R. V. Ovcharov, S.A. Raschetina, A. B. Chistova, L. M. Shipitsina, and others) has a clear socio-pedagogical context. [3]

In General, social pedagogical support is understood as a system of measures that ensure the protection of human rights, including those that meet the social needs of special children.

In General, at least food, clothing, housing, medical and socio-pedagogical assistance should be provided for the life of any teenager - preserving his or her health and ensuring the well-being of his or her family. If the family does not have the necessary means to recover (unemployment, pain, disability, old age, or loss of a breadwinner), the school's social teacher must provide students with the protection and support provided by the state.

Today, the problem of educating the younger generation is one of the most urgent one. Our society is experiencing a social and spiritual crisis. Kazakhstan approved the "Convention on the rights of the child", adopted by the UN in 1989. The content of the Convention sets 4 main requirements: the right of the child to 
life, protection and support of the child, creation of conditions for development, and respect for the right to active participation in public life. The main priority is not non-discrimination of the child for any reason. The Convention pays special attention to socially vulnerable groups of children, orphans, disabled people, and offenders.

And the difference in social and pedagogical support is as follows:

- social and pedagogical support is aimed at preventive assistance to the child in solving their problems in the educational process and social environment.;

- social and pedagogical support, development of a humanistic personality in accordance with educational models of education, perception in relationships, assistance to the teacher of the child's living conditions in a constrained situation "you can" - in order to learn how to solve their own problems;

- social and pedagogical support is necessary not only by solving human problems, but also in conditions that prevent their education in the process of socialization;

- social-pedagogical support is targeted by a person or group to avoid, alleviate, or eliminate causes that act as risk factors that hinder self-development;

- social and pedagogical support is aimed at developing a person's adaptive abilities and individual growth of their interaction with the social environment. [4]

Research of a social teacher: defining categories of students, conducting sociological research of each of them, analyzing the health of disabled children, and interviewing teachers to evaluate the school's performance. Working with different categories of children: working with families of disadvantaged adolescents who are the object of our research: providing systematic assistance to families in difficult situations in diagnostic, preventive, social, social, psychological, organizational areas.

In developed models of socio-pedagogical support, adolescents are considered as objects of sociopedagogical influence. Thus, the object of social and pedagogical support is: children with disabilities, orphans, children who are offenders, children at risk - with developmental problems without pronounced clinical and pathological characteristics; those left without parental care; and so on.

Another form of social pedagogue's work with families is social and pedagogical monitoring of the family - a scientifically based system of step-by-step collection, generalization and analysis of information about the processes taking place in the family, and on this basis, making strategic and tactical decisions. [5]

In the process of providing pedagogical support to children, the social teacher makes efforts to preserve and preserve their views, life goals, and moral qualities. They should assess the spiritual characteristics, emotional state of the wards, and be aware of the family situation. [6] therefore, the social teacher always keeps in touch with the students ' families. In order to work as a social teacher with a low-income family, I briefly focused on several works: the social passport of the student, the act of examining the living conditions of the student, the characteristics of the student's family, and the journal of social and pedagogical accounting.

Now an ACT of examination of the material and residential living conditions of the student's family is being drawn up. It examines the family composition, living conditions, General month, private apartment, rented housing, sanitary conditions, the lack of individual spaces of the child staying in the room, the child's behavior in the house, communication with the child's parents, relatives, their children, other features discovered during the preparation of the act, conclusion, suggestion, etc. The home visit certificate is stored in the student's Social passport and provides a description of the family for the successful work of a social teacher, especially in relation to a family that needs special attention.

The social teacher, when visiting the family, determines the marital status and at the end of the family briefing fills in the accounting log. And he is helped by a magazine of consultations on monitoring the stages of working with the family. A detailed description of parental counseling is entered in the student's Social passport, which records the work done. In the social security journal, it is noted which family and on what basis social benefits are provided (benefits, provision of free food), about its implementation and provision. Employees of these services at the school are directly responsible for providing students with hot meals and access to new clothing.

Of course, the provision of such financial assistance by a social teacher is made in accordance with the Law of the Republic of Kazakhstan "On state targeted social assistance". 


\section{The journal «Social security»}

\begin{tabular}{|l|c|c|c|c|}
\hline Date & $\begin{array}{c}\text { Students' full } \\
\text { name }\end{array}$ & $\begin{array}{c}\text { The problem and } \\
\text { necessity }\end{array}$ & $\begin{array}{c}\text { Regulation of the issue } \\
\text { (social services) }\end{array}$ & $\begin{array}{c}\text { Progress, date of } \\
\text { execution. }\end{array}$ \\
\hline
\end{tabular}

The ability of a social educator to focus on the child's problems, establish open relationships with them, fully conceptually, significantly affects the implementation of social education. As a result of this connection, the work of a social teacher in schools will find its own system.

In schools with children from disadvantaged families, the tasks and functions of a responsible social teacher are briefly systematized:

- first, it deals with the study of individual psychological characteristics of the student;

- in the next situation, the situation will consistently solve problems and regulate difficult situations to adapt the child to the social environment, his efforts to develop personal qualities;

- it works to provide assistance, property and non-property rights of the child on the part of the state;

- it organizes the child's free time, his connection with the school, society, and team;

- participates in the development, approval and implementation of educational programs of educational organizations.

Financial situation is one of the reasons that determine the status of a person in the society in which the person lives. Providing children with the necessary clothing, food, and training facilities certainly affects their future life and psychological state. Therefore, social educators monitor the provision of social and material assistance to children from low-income and low-income families.

As the main results of individual socio-pedagogical support for a teenager from low-income families, we:

- setting up a trusting relationship with your family;

- teenagers and parents with a teacher and social relationships, and satisfaction;

- overview of the development of new social roles for adolescents;

- social initiative, active participation in collective creative activities; and a conscious approach to choosing a future profession, professional training, etc. [7]

Children, teenagers, and their caregivers ask for help from a social teacher during a difficult period of life. They are disappointed in life, lost hope, experienced difficulties and were not able to solve the problem on their own, waiting for understanding, goodwill, moral support and real help. Helping them in word and deed, promoting their self-belief, and reviewing and maturing their values is the main task of a social educator. Understanding and caring for children and adolescents is the main mission of a social educator.

If families in society differ in different social conditions, then they are low-income families, children who are brought up in this family are the focus of attention of social educators. After all, the child, seeing the lack of life, negative moments in the family, feeling the lack of attention of parents, may be a little less than the warmth of the family. A future citizen or citizen who has been exposed to such negative factors can have a negative impact on the society in which the citizen lives. The work of a social educator in preventing such accidents and turning the lives of low-income teenagers in the right direction is important. Therefore, we would like to organize the campaign "Road to school-2020" for low-income, low-income families, children and teenagers, as well as open recreation and Health improvement centers for children from low-income families.

\section{References:}

1. World of science and education in Kazakhstan. Republican scientific-methodical and pedagogical journal No. 3, 2006.

2. Information and legal system of normative legal acts of the Republic of Kazakhstan.

3. O.S. Gazman Pedagogy of freedom the path to humanistic civilization. - 2000. - No. 3-With 6-33

4. Sociology pedagogy journal no 1.2.3 M 2007

5. B.Aitbaeva Fundamentals of social pedagogy: a textbook. - Almaty: Kazakh University, 2011 - 165 p.

6. L.V. Mardahaev, "Methodology and technology of social educator»"

7. Duisenbekova sh Social pedagogy: textbook. - Semipalatinsk: Semipalatinsk state pedagogical Institute, 2010. - 81 b. 